\title{
Blood profile of prevalent sheep breeds in Nigeria: A case study of Ikorodu Local Government Area of Lagos State, Nigeria
}

${ }^{1}$ Agbaye, F. P., ${ }^{2}$ Sokunbi, A. O., ${ }^{1}$ Onigemo, M. A., ${ }^{2}$ Alaba, O., ${ }^{1}$ Anjola, O. A. J., ${ }^{3}$ Amao, E. A., ${ }^{1}$ Agbalaya, K. K., ${ }^{2}$ Oso, Y. A. A., ${ }^{1}$ Ishola, O. J., ${ }^{1}$ Tijani, L. A. and ${ }^{1}$ Timothy, T. ${ }^{I}$ Department of Animal Production Technology, Lagos State Polytechnic, Lagos

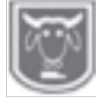

${ }^{2}$ Department of Animal Science, University of Ibadan, Ibadan.

${ }^{3}$ Department of Animal Production Technology,

The Oke Ogun Polytechnic, Saki.

Abstract

The role of the environment in the survivability of an animal is paramount and blood profiles are part of the indices for measuring the health status. Therefore, a study was carried out to determine the blood profile of prominent indigenous breed of sheep (Ram) viz: West African Dwarf, Yankasa, Balami and Ouda breeds reared in Ikorodu Local Government. A total of 20 rams were used comprising of five rams per breed, with average age of $2^{1 / 2}$ years weighing $31.13 \pm 4.8 \mathrm{~kg}$. Blood samples were carefully collected from the rams into labeled sterile bottles containing EDTA for haematological examination and another set of bottles containing Lithium Heparin was used to collect blood for the serum biochemical analysis. Haematological parameter assessed were Packed Cell Volume (PCV), White Blood Cell $(W B C)$, Red Blood Cell (RBC), while the biochemical parameters investigated were Total protein (Tp), Albumin, Glucose, Creatine Cholesterol, and Alkaline phosphatase (ALP). $P C V$ was significantly $(p<0.05)$ highest $(32.25 \%)$ in Yankassa and lowest (26.25\%) in Ouda. Yankasa had statistically ( $p<0.05)$ the higher 11.66g/dL Hb, followed by WAD (10.00), Ouda (9.60) and lower (9.20) in Balami. RBC (x10/ml) was significantly $(p<0.05)$ higher in WAD (3.72) than other breeds and lowest in Ouda (3.11). MCV (fl) value was significantly lower in Yankasa (75.83) than other breeds and higher in Ouda (83.60). MCH (pg) was statistically $(p<0.05)$ highest (30.89) in Yankasa and lower (26.93) in Balami. Yankasa had significantly $(p<0.05)$ the higher (8673.00) Total WBC $\left(\mathrm{mm}^{3}\right)$, followed by WAD (8453.25), Balami (6814.25) and least in Ouda (6718.75). Total protein was significantly $(p<0.05)$ the higher (53.76) in WAD ram and lower (43.76) in Ouda. Yankasa ram recorded significantly $(p<0.05)$ the higher Albumin content (5.45), glucose level (48.87), ALP (129.71) and significantly the least creatine (0.63) while significantly $(p<0.05)$ the least values for Glucose were in Ouda (44.83), Albumin content and Alkaline phosphatase in Balami (4.33, 104.87 respectively). Cholesterol value was significantly the higher (93.22) in WAD and lower (79.70) in Balami. Results revealed significant differences in haematological and serological indices tested though all values obtained were within the normal range for sheep.

Keywords: Blood Profile, Sheep Breed, Ikorodu local government area

Profil sanguin des races de moutons prévalentes au Nigeria: étude de cas de la collectivité locale d'Ikorodu dans l'État de Lagos, Nigeria

\section{Résumé}

Le rôle de l'environnement dans la survie d'un animal est primordial et les profils sanguins font partie des indices de mesure de l'état de santé. Par conséquent, une étude a été menée pour déterminer le profil sanguin de la race indigène de moutons (bélier), à savoir: les moutons nains d'Afrique de l'Ouest (WAD), Yankasa, Balami et Ouda élevés dans la collectivité locale d'Ikorodu. Au total, 20 béliers ont été utilisés comprenant cinq béliers par race, avec un âge moyen de 2 ans et demi pesant $31,13 \pm 4,8 \mathrm{~kg}$. Des échantillons de sang ont 


\section{Blood profile of prevalent sheep breeds in Nigeria}

été soigneusement prélevés sur les béliers dans des flacons stériles étiquetés contenant de l'EDTA pour un examen hématologique et un autre ensemble de flacons contenant de l'héparine de lithium a été utilisé pour collecter du sang pour l'analyse biochimique du sérum. Les paramètres hématologiques évalués étaient le volume de cellules emballées $(P C V)$, les globules blancs (WBC), les globules rouges (RBC), tandis que les paramètres biochimiques étudiés étaient la protéine totale (Tp), l'albumine, le glucose, la créatine cholestérol et la phosphatase alcaline $(A L P)$. Le PCV était significativement $(p<0,05)$ le plus élevé (32,25\%) à Yankassa et le plus bas (26,25\%) à Ouda. Yankasa avait statistiquement $(p<0,05)$ le taux d'Hb le plus élevé de 11,66 $\mathrm{g} / \mathrm{dL}$, suivi de WAD $(10,00)$, Ouda (9,60) et moins (9,20) à Balami. Les globules rouges $(x 10 / \mathrm{ml})$ étaient significativement $(p<0,05)$ plus élevés chez WAD $(3,72)$ que chez les autres races et plus faibles chez Ouda $(3,11)$. La valeur MCV (fl) était significativement plus faible à Yankasa $(75,83)$ que dans les autres races et plus élevée à Ouda (83,60). MCH (pg) était statistiquement $(p<0,05)$ la plus élevée $(30,89)$ à Yankasa et inférieure $(26,93)$ à Balami. Yankasa avait significativement $(p<0,05)$ le plus élevé $(8673,00)$ WBC total (mm3), suivi des moutons nains d'Afrique de l'Ouest, (8453,25), Balami (6814,25) et inférieur à Ouda $(6718,75)$. La protéine totale était significativement $(p<0,05)$ la plus élevée $(53,76)$ chez les moutons nains d'Afrique de l'Ouest, et la plus faible $(43,76)$ chez Ouda. Le bélier Yankasa a enregistré de manière significative $(p<0,05)$ la plus haute teneur en albumine $(5,45)$, le niveau de glucose $(48,87)$, l'ALP $(129,71)$ et significativement le moins de créatine $(0,63)$ tandis que de manière significative $(p<0,05)$ les valeurs les plus faibles pour le glucose étaient à Ouda (44,83), teneur en albumine et phosphatase alcaline chez Balami (4,33, 104,87 respectivement). La valeur du cholestérol était significativement la plus élevée $(93,22)$ chez les moutons nains d'Afrique de l'Ouest et la plus basse $(79,70)$ chez Balami. Les résultats ont révélé des différences significatives dans les indices hématologiques et sérologiques testés bien que toutes les valeurs obtenues se situent dans la plage normale pourles moutons.

Mots clés: Profil sanguin, race de mouton, collectivité locale d'Ikorodu

\section{Introduction}

In Nigeria small ruminant is about $63.7 \%$ of total grazing domestic livestock. They are widely distributed in rural, urban and periurban area. There are estimated 42.1million indigenous sheep in Nigeria (NASS, 2011). The indigenous breeds of sheep in order of importance are Yankassa West African Dwarf Ouda and Balami. The vast majority of these small ruminants are found in the northern savannah zone. Sheep are estimated to contribute $11 \%$ of the meat supply from the slaughter houses in the Nigeria. Sheep rearing is taken a leading role in the sustainable rural development programmes in developing countries (Rastogi, et al., 2006). Physiological and pathological changes in an organism can be detected through the blood indices (Mitruka and Rawnsley, 1977). The primary function of the blood is to transport oxygen from the respiratory organ to the body cells (Duke, 2000) and distribution of nutrient enzymes to the cells and carrying away waste products (Slaker and Suverton, 2005), thereby maintaining homeostasis of the internal environment (Bentrick, 2009) the various functions of the blood are carried out by the individual and collective action of its constituent the haematology and biochemistry components (Akinmutimi, 2004). Haematological test is widely used for the diagnosis of various diseases and nutritional status of animals. The haematological and serum biochemical 


\section{Agbaye, Sokunbi, Onigemo, Alaba, Anjola, Amao, Agbalaya, Oso, Ishola, Tijani and Timothy}

profile provide reliable information on the health status of animals (Cetin, et al., 2009). Also, it helps in determine the extent of tissue and organ damage, the response of defense mechanism of the animal and diagnosing the type of possible anaemia (Weaver, 2005). Significant variation could occur in blood parameter due to altitude, management, feeding level, age, sex, breeds, health status, method of blood collection, haematological techniques used, seasonal variation, ambient temperature and physiological status such as excrement, muscular, water balance and transportation (Ewuola, et al., 2008). Physiological and pathological changes can be best evaluated when normal blood values are available for comparison. Even though considerable information is available on the normal blood parameters of domestic animals the values are that of exotic breeds kept under different environment and management conditions (Tibbo, et al., 2004). Therefore, this study is aimed at comparing the haematological and biochemical indices of the indigenous breeds of sheep in Nigeria.

\section{Materials and methods \\ Experimental site}

The experiment was carried out at the small ruminant unit of the Animal Production Technology Department of Lagos State Polytechnic, Ikorodu, Lagos state.

\section{Experimental animals and management}

Twenty matured rams comprising of five rams per breed from the four prominent breeds with average age of $2 \frac{1}{2}$ years weighing between $31.13 \pm 4.8 \mathrm{~kg}$ viz: Yankassa, Ouda, West African Dwarf (WAD) and Balami were purchased and managed in the small ruminant unit of the Polytechnic Teaching and Research Farm and were managed for a period of four weeks to acclimatize and for necessary prophylactic medication before the commencement of the experiment. The rams were allowed to graze within the paddock around the small ruminant housing unit and water was given ad-libitum. Salt leak and supplementary feeds (wheat offal) were given once a day.

\section{Data collection and analysis}

Blood samples were collected from the jugular vein of each ram using $10 \mathrm{~mL}$ needle and syringe per week for a period of six weeks. $5 \mathrm{~mL}$ of the blood collected were discharged into sample bottle containing EDTA for haematological studies and another $5 \mathrm{ml}$ into Lithium Heparin bottle for serum biochemistry. The samples were analyzed for the following haematological parameters: Packed cell volume (PCV) and Haemoglobin ( $\mathrm{Hb})$ was determined according to procedure described by Dacie and Lewis (2001), RBC and WBC were evaluated by method outlined by Jain (1986) Mean Corpuscular Haemoglobin Concentration (MCHC) Mean Corpuscular Haemoglobin (MCH) Mean Corpuscular Volume (MCV) values were calculated according to formulae of Patterson et al., (1960). The total protein (Tp) was determined based on Biuret reaction (Dioumas, et al., 1981) and Albumin was determined as described Dioumas and Biggs (1972). Creatinine determination was done according to method of Ambrose, et al., (1983). Cholesterol levels were estimated using the principles of Huang et al., (1961) and modified by Ness, et al., (1962). All data collected were subjected to analysis of variance (ANOVA) for a (CRD) according to the standard procedure as describe by Steel and Torries (2002). Duncan multiple range test was used to compare the means

\section{Result and discussion}

Result in Table 1 shows the summary of haematological values for the experimental animals. The packed cell value (PCV) deferred significantly $(\mathrm{P}>0.05)$ between breeds with Yankassa ram having the higher PCV (32.25\%), Hb (11.66g/dL) and WBC 


\section{Blood profile of prevalent sheep breeds in Nigeria}

$(11.66 \mathrm{~g} / \mathrm{dL})$ values. The higher value of RBC $(3.72 \times 10 / \mathrm{mL})$ was observed in Balami ram while Ouda ram had the least $(3.11 \mathrm{~g} / \mathrm{dL})$ value of $\mathrm{MCH}$ ranges from (26.93-30.89pg) with Ouda ram having the highest value while Balami ram had the least (26.93pg). The highest value of $(36.95 \mathrm{~g} / \mathrm{dL})$ was observed in Ouda ram for MCHC. Ouda ram was observed to have the higher MCV. Yankassa ram had the highest value for WBC $(11.66 \mathrm{~g} / \mathrm{dL})$. The lymphocytes value ranged from $48.50 \%$ in WAD to $55.00 \%$ in Yankassa and Balami ram, respectively. The higher value for Neutrophils was observed in Ouda and WAD ram $(51.00 \%)$ while Yankassa ram had the least (44.00\%). PCV (26.25$32.25 \%$ ) values were within the normal range ( 28.90 to $30.25 \%$ ) reported by various authors (Rusuff, et al., 1954, Bianca, 1955 and Baneejee, 2007). An increase in PCV might be attributed to high environmental temperature. This is similar to the report of Patterson, et al. (1960) which report that increase in environmental temperature cause an increase in PCV. The result of the $\mathrm{Hb}$ content showed that the value ranged from (9.20-11.66 g/dl) with Yankassa having the higher value. The normal $\mathrm{Hb}$ range was 8-16 $\mathrm{g} / \mathrm{dL}$ reported for sheep (RAR, 2009). The increase in $\mathrm{Hb}$ concentration is associated with greater ability to resist infection and low level is an indication of infection and poor nutrition (Cheesbrough, 2004; Tambuwal et al., 2002). The RBC value was observed to be higher in WAD. But the value (3.11-3.72) obtain in this study were within the normal value recommended (Campbell et al., 2003). The value of MCV (75.83-83.60), $\mathrm{MCHC}$ and $\mathrm{MCH}$ significantly increased and are very important in the diagnosis of anaemia and also serve a useful index of the capacity of the bone marrow to produce RBC (Awodi, et al., 2005). The WBC count was observed to be higher in Yankassa (8673.00). The higher WBC in this study is an indicator of immune response to infections or toxic substances in the animal and a low count is an indication of pathogenic infection or presence of antigen in the organism (Bradbury, et al., 1999). There was no significant difference in the Lymphocyte and Neutrophils of the entire breed.

Table 1: Haematological values of four breeds of ram

\begin{tabular}{|c|c|c|c|c|c|}
\hline \multirow{2}{*}{ Parameter } & \multicolumn{4}{|c|}{ Breeds of ram } & \multirow{2}{*}{ SEM } \\
\hline & Balami & Yankassa & Ouda & WAD & \\
\hline PCV (\%) & $28.00^{\mathrm{b}}$ & $32.25^{\mathrm{a}}$ & $26.25^{\mathrm{b}}$ & $30.25^{\mathrm{a}}$ & 1.30 \\
\hline $\mathrm{Hb}(\mathrm{g} / \mathrm{dl})$ & $9.20^{\mathrm{c}}$ & $11.66^{\mathrm{a}}$ & $9.60 b^{c}$ & $10.00^{\mathrm{b}}$ & 0.54 \\
\hline $\mathrm{RBC}(\mathrm{x} 10 / \mathrm{ml})$ & $3.40^{\mathrm{b}}$ & $3.41^{\mathrm{b}}$ & $3.11^{\mathrm{b}}$ & $3.72^{\mathrm{a}}$ & 0.12 \\
\hline $\mathrm{MCH}(\mathrm{pg})$ & $26.93^{b}$ & $27.70^{\mathrm{b}}$ & $30.89^{\mathrm{a}}$ & $27.53^{b}$ & 0.89 \\
\hline $\operatorname{MCV}(\mathrm{fl})$ & $82.11^{\mathrm{a}}$ & $75.83^{b}$ & $83.60^{\mathrm{a}}$ & $80.95^{a}$ & 1.68 \\
\hline $\mathrm{MCHC}(\mathrm{g} / \mathrm{dl})$ & $32.78^{\mathrm{c}}$ & $36.48^{\mathrm{a}}$ & $36.95^{\mathrm{a}}$ & $33.90^{\mathrm{b}}$ & 1.00 \\
\hline $\mathrm{WBC}\left(\mathrm{mm}^{3}\right)$ & $6814.25^{\mathrm{c}}$ & $8673.00^{\mathrm{a}}$ & $6718.75^{\mathrm{d}}$ & $8453.25^{\mathrm{b}}$ & 520 \\
\hline Lymphocytes \% & 55.00 & 55.00 & 49.00 & 48.50 & 1.80 \\
\hline Neutrophils \% & 45.00 & 44.00 & 51.00 & 51.00 & 1.96 \\
\hline
\end{tabular}

Table 2 shows serum biochemistry of the rams. All the parameters showed significant difference $(\mathrm{P}<0.05)$ between breeds. The value for total protein concentration, albumin, glucose, alkaline obtained were higher in Yankassa the creatinine and globulin were significantly higher $(\mathrm{P}<0.05)$ in WAD ram than any of the breed. Serum biochemical indices is used to determine the level of heart defects, liver damage, evaluate protein quality and amino acid requirement in animals as reported by 
(Harper, et al.,1979). The values of total protein concentration obtained were higher in Yankassa and Ouda ram than other breeds. This agrees with the report of Kamalu, et al., (1988). Plasma protein helps to transport calcium and phosphorus and other substances in the blood by attaching to the albumin. The Albumin values obtained in the present study was higher (5.45) in Yankassa ram than other breeds. Value of albumin less than the normal value usually indicates hypo albumineamia (Altman, 1979). The Glucose levels show that Yankassa had the higher glucose level. When glucose is lower than the normal range is an indication of hypoglycemia Olorunnisomo, et al., (2012). The creatinine value of the present study was within normal range and were different significantly $(\mathrm{p}<0.05)$ among the breeds. High creatinine is indication of poor protein and amino acid metabolism that can lead to impaired renal function and cardiac infraction (Gray and Howarra, 1980). The cholesterol value shows inconsistency for breed. If the blood cholesterol is high it may result in its deposition on the walls of the blood vessels and these deposits may eventually result to atherosclerotic plaque, this may block important blood vessels and result in a myocardial infraction. The alkaline phosphatase showed a significant difference $(p<0.05)$ among the breed, Yankassa ram having the highest.

Table 2: serum biochemical result of different breed of ram

\begin{tabular}{llllll}
\hline \multirow{2}{*}{ Parameter } & \multicolumn{4}{c}{ Breeds of ram } & \multirow{2}{*}{ SEM } \\
\cline { 2 - 5 } & Balami & Yankassa & Ouda & WAD & \\
\hline Total protein $(\mathrm{g} / \mathrm{l})$ & $52.37^{\mathrm{b}}$ & $53.19^{\mathrm{a}}$ & $43.76^{\mathrm{c}}$ & $53.76^{\mathrm{a}}$ & 2.35 \\
Albumin $(\mathrm{g} / \mathrm{dl})$ & $4.33^{\mathrm{c}}$ & $5.45^{\mathrm{a}}$ & $4.84^{\mathrm{c}}$ & $5.15^{\mathrm{b}}$ & 0.23 \\
Glucose $(\mathrm{mg} / \mathrm{dl})$ & $45.44^{\mathrm{c}}$ & $48.87^{\mathrm{a}}$ & $44.83^{\mathrm{d}}$ & $47.64^{\mathrm{b}}$ & 0.94 \\
Creatinine $(\mathrm{mg} / \mathrm{dl})$ & $0.75^{\mathrm{b}}$ & $0.63^{\mathrm{d}}$ & $0.65^{\mathrm{c}}$ & $0.77^{\mathrm{a}}$ & 0.03 \\
Cholesterol $(\mathrm{mg} / \mathrm{dl})$ & $79.70^{\mathrm{d}}$ & $85.72^{\mathrm{b}}$ & $84.21^{\mathrm{c}}$ & $93.22^{\mathrm{a}}$ & 2.81 \\
Alkaline phosphates $(\mathrm{i} . \mathrm{u} / \mathrm{l})$ & $104.87^{\mathrm{d}}$ & $129.71^{\mathrm{a}}$ & $118.68^{\mathrm{c}}$ & $120.05^{\mathrm{b}}$ & 5.11 \\
\hline a,b,c,d & mean having different superscript letters in the same row differ significantly $(\mathrm{p}<0.05)$ &
\end{tabular}

\section{Conclusion}

From the present study, it can be concluded that the haematological and biochemical parameters differs from one breed to another. Nutrition, age and other environmental factors pose great influence on the blood profile of sheep in the tropics

\section{References}

Akinmutimi, A. H. 2004. Evaluation of sword Bear Canavalia gladiate as an alternative feed resources for broiler chickens Ph.D Thesis Micheal Okpara University of Agriculture, Umudike, Nigeria.

Altman, R. B. 1979. Avian Clinical Pathology, Radiology Parasitic and Infections disease in proceedings of American animal hospitals association, south Bend.IN.

Ambrose, R. T., Ketchum, D. F. and Smith, J. W. 1983. Creatinine determined by "High performance" Liquid Chromatography. Clinical Chemistry: 29:256-259.

Awodi, S., Ayo, J. O., Atodo, A. D. and Dzende, T. 2005. S o me Haematological parameters and the Erythrocyte osmotic Fragility in the laughing Dove (Streptopella senegelensis and the village weaver bird (ploceus scucullatus), In: Chineke, C.A.

Bannejee, G. C. 2007. A textbook of animal husbandary $8^{\text {th }}$ Edn. published by Raju primlani for Oxford and IBJ Publishing Co.PVT LTD, New 


\section{Blood profile of prevalent sheep breeds in Nigeria}

Delhi Pp1079.

Bentrick, S. 2009. Heamatology Textbook of Veterinary PATHOLOGY. Publ Williams and co Baltimore pp.217_224.

Bianca, W. 1955. The effect of repeated short exposure to heat on the volume and hydration of the blood of the calf. British veterinary journal 43:171-180

Bradbury, M. G, Egan, S. V. and B r a d bu ry, J. H. 1999 . Determination of all Forms of Cyanogen in Cassava roots and Cassava. Products using picrate paper kits. J.S. clinical cases of Small Ruminant in Zaria Nigeria, Bulletin of Animal Heath and production in Africa 30,111-116.

Campbell, J. R., Kenealy, M. D. and Campbell, K. E. 2003. Animal science. The Biology, Care and Production of Domestic Animals McGraw Hill U.S.A Pp 510.

Cetin, N., Bekyurek, T. and Cetin, E. 2009. Effect of sex, pregnancy and season on some haematological and Biochemical blood values in Angora rabbit. Scand. J. Lab. Anim. Sci.36(2):155-162.

Cheesbrough, M. 2004. District Laboratory Practice in tropical countries part 2 University press Cambridge United Kingdom, 266342.

Dacie, J. V. and Lewis, S. M. 2001. Practical Heamatology $9^{\text {th }}$ ed. Churchill Livingstone, London, $\mathrm{p}$ 633.

Doumas, B., Bayso, D. D., Carter, R. J., Peter, T. and Schaffer, R. 1981. A candidate reference method for determination of total protein in serum: Development and validation. Clinical Chemistry; 27:1642.

Doumas, B. T. and Biggs, H. G. 1972.
Determination of serum albumin. Standard method of Clinical Chemistry; 7: 175-188.

Duke, H. H. 2000. Physiology of Domestic Animals Livestock publishing Associate A Division of Nornell University Press. Ithaca and London Pp 23-61.

Ewuola, E. O. and Egbunike. G. N. 2008. Heamatological and serum biochemistry response of growing rabbit bucks fed dietry fumonisin B 1. Africal Journal of Biotechnology. Vol.7(23), 43044309.

Gray, C. H. and Howarth, P. J. N. 1980. Clinical Chemical pathology $9^{\text {th }}$ Edn. English language Book Society and Edward Arnold (Publishers) Ltd London.

Harper, H. A., Rodwell, V. W. and Mayer, P. A. 1979. Review of physiological chemistry $6^{\text {th }}$ Edn. California Lenge Medical Publishers. Pp559-598.

Huang, T. C., Cheng, C. P., Wefler, V. and Raftery, A. 1961. A stable reagent for the Liebermann-Buchard reaction. Analytical Chemistry. 33:1405-1407.

Jain, N. C. 1986. Schalm Veterinary Haematology. $4^{\text {th }}$ ed. Lea and Febiger, Philadelphia, U.S.A.

Kamalu, T. N; Sheffy, S. N. and Nair, S. G. (1988). Biochemistry of Blood of West African dwarf Goats Trop Vet 1988; 6:2-5. 54. Lamb GN. Manual of veterinary by BC Pradhan 2016 .

Mayes, P. A. 1979. Regulation of carbohydrate and lipid metabolism. In: Review of Physiological Chemistry. (Eds; H. A. Harper, V. W. Rodwell and P.A. Mayes). 1979. Lange Medical Publication, California.

Mitruka, B. M. and Rawnslay, H. M. 1977. Clinical Biochemical and 
Haematological Reference value in Normal Experiment Animals, Masson Publication, New York, U.S.A.Pp 21-64.

NASS, 2011. National Bureau of Statistics/Federal Ministry of Agriculture and Rural Development Collaborative Survey on National Agriculture Sample Survey (NASS), 2010/2011

Ness, A. T., Pastewka, J. V. and Peacock, A. C. 1962. Evaluation of recently reported stable LiebermannBuchard reagent and its use for direct determination of serum total cholesterol. Clinical Chemical Acta, 10:229-237.

Olorunnisomo, O. A, Ewuola, E. O. and Lawal, T. T. 2012. Intake and blood metabolites in Red Sokoto Goats fed Elephant Grass and Cassava peel Silage. Journal of Animal Production Advances.2 (a ) : 420 428.ISSN:2251-7677.

Patterson, T. B., Shrode, R. R., Kunkel, H. O., Leighton, R. E. and Rupel, I. W. 1960. Variations in certain blood components of Hoistein and Jersey cows and their relationship to daily change in rectal Temperature and Milk and Butter fat Production. Journal of Diary Science 43;1263-1274.

Rastogi, A., Dutta, N. and Sharma, K. 2006. Effect of strategically supplemented pregnancy allowance on nutrient utilization and reproductive performance of goats. Livestock Res. Rural Dev., Vol. 18.
Research Animal Resources (RAR) 2009. Reference value for laboratory animals. Normal haematological value.

Rusoff, L. L., Johnston, J. E. and Branton, C. 1954. Blood studies of Breeding Dairy Bulls. Journal of Dairy Science 47:30-36.

Steel, R. G. D. and Torrie, J. H. 2002. Principles and procedures of statistics, McGraw-Hill, New York.

Tambuwal, F. M., Agbale, B. M. and B a $\mathbf{n}$ g a n a, A. 20002 . Haematological and Biochemical Values of Apparently Healthy Red Sokoto Goats. In Proceeding of $27^{\text {th }}$ ANNUAL Conference Nigerian Society of Animal Production (NSAP), March, 17-21,2012, FUTAAkure, Nigeria.

Tibbo, M., Jibril, T., Woldemeskel, M., Dawo, F., Aragaw, K. and Rege, J. E. O. 2004. Factors affecting haematological profiles in three Ethiopian indigenous goat breeds. Intern. J. Appl. Res. Vet. Med. 2(4): 297-309.

Weaver, S. 2005. Sheep: Small, scale sheep keeping for pleasure and profit, U.S.A. Irvine, ca: hobby farm press. ISBN 978-1-931993-49-4.

Wallen, J. D. 1979. The kidney and the Urine. In: Review of Physiological Chemistry (Eds; H. A. Harper, V. W. Rodwell and P. A. Mayes). 1979. Lange Medical Publication, Califonia.

Received: $5^{\text {th }}$ December, 2020 Accepted: $11^{\text {th }}$ March, 2021 